\title{
PAWEE WYGRALAK \\ Sposoby udzielania Komunii św. w starożytnych wspólnotach chrześcijańskich. Nauczanie Ojców Kościoła i wskazania synodalne (II-VIII w.)
}

Kongregacja ds. Dyscypliny Sakramentów wydała w 1973 roku instrukcję Immensae caritatis, w której przypomniano, że w Kościele katolickim obowiązuje zasada przyjmowania Komunii św. „do ust”. Udzielanie Komunii „na rękę” jest możliwe, ale po otrzymaniu zezwolenia Stolicy Apostolskiej ${ }^{1}$. Takie pozwolenia były wydawana na prośbę Konferencji Episkopatów wielu krajów, co potwierdza Jan Pawła II w Liście apostolskim Dominicae Cenae z 24 lutego 1980 r. $(\mathrm{nr} 11)^{2}$. W watykańskiej instrukcji Redemptionis sacramentum, z dnia 23 kwietnia 2004 r. dopuszcza się możliwość udzielania Komunii św. „na rękę”. W punkcie 92 czytamy: Chociaż każdy wierny zawsze ma prawo wedtug swego uznania przyjąć Komunię święta do ust, jeśli ktoś chce ja przyjąć na rękę, w regionach, gdzie Konferencja Biskupów, za zgoda Stolicy Apostolskiej, na to zezwala, należy mu podać konsekrowana Hostię. Ze szczególna troska trzeba jednak czuwać, aby natychmiast na oczach szafarza ja spożyt, aby nikt nie odszedt, niosąc $w$ ręku postacie eucharystyczne. Jeśli mogłoby zachodzić niebezpieczeństwo profanacji, nie należy udzielać wiernym Komunii świętej na rękę ${ }^{3}$.

W Polsce problemem sposobu udzielania Komunii św. zajął się II Synod Plenarny w 1999 r., którego dokumenty zostały zatwierdzone przez Stolicę Apo-

Paweł W Y GR A L A K, ks. dr hab., adiunkt w Zakładzie Teologii Patrystycznej, WT UAM, Poznań, rektor Arcybiskupiego Seminarium Duuchownego w Poznaniu, e-mail: pawelwyg@amu.edu.pl

${ }^{1}$ Por. Kongregacja Kultu Bożego i Dyscypliny Sakramentów: Instrukcja Immensae caritatis 4. AAS 65 (1973), 270.

${ }^{2}$ Por. J a n P a w e 1 I I: List apostolski Dominicae Cenae. AAS 72 (1980), 141.

${ }^{3}$ Por. Kongregacja do spraw Dyscypliny Sakramentów: Instrukcja Redemptionis sacramentum. AAS 96 (2004), 577. 
stolską w 2001 r. Ojcowie synodalni w dokumencie Liturgia Kościoła po Soborze Watykańskim II w punkcie 92 ustalili: Synod Plenarny potwierdza $i$ wyraża szacunek dla zwyczaju przyjmowania Komunii św. »do ust «w postawie zarówno klęczacej, jak i stojacej, nie wykluczajac jednak innych form przyjmowania Komunii św., $z$ zachowaniem najwyższej czci dla Eucharystii ${ }^{4}$. Mimo to w wielu wypowiedziach ciągle jeszcze zgłasza się wątpliwość co do dopuszczalności przyjmowania Komunii św. „na rękę”. Niejednokrotnie przeciwnicy tej formy komunikowania powołują się na wielowiekową tradycję Kościoła udzielania Komunii św. „do ust”.

Zatem przedmiotem niniejszego artykułu jest analiza wypowiedzi Ojców Kościoła i uchwał synodów starożytności chrześcijańskiej omawiających sposoby udzielania wiernym Komunii św.

\section{Komunia św. „na rękę” w pouczeniach Ojców Kościoła}

Arcybiskup Stanisław Gądecki w Liście pasterskim o sposobach przyjmowania Komunii świętej: Eucharystia tworzy komunię $i$ wychowuje do komunii z dnia 13 marca 2005 r. stwierdził, że praktyka podawania Komunii na rękę nawiązuje w pierwszym rzędzie do przekazu ewangelicznego opisującego ustanowienie Eucharystii przez Jezusa Chrystusa: [...] wzią chleb, odmówiwszy dziękczynienie połamat go i podat mówiąc: To jest Ciało moje, które za was będzie wydane: to czyńcie na moja pamiatkę! (Łk 22,19) ${ }^{5}$. Zatem to sam Chrystus gestem podania Swego Ciała do rąk apostołów zainicjował praktykę udzielania Komunii św. „na rękę”.

Najprawdopodobniej w taki sam sposób postępowały pierwotne wspólnoty chrześcijańskie. Niestety, w jednym z najstarszych i najszerszych opisów starożytnej celebracji Eucharystii, który pozostawił św. Justyn (†167), brak jest informacji na temat. Autor skoncentrował się na opisie przebiegu całej Eucharystii, zaznaczając jedynie, że wszystkim nieobecnym Komunia św. jest zanoszona przez diakonów ${ }^{6}$. Jednak pochodząca $\mathrm{z}$ tego samego wieku inskrypcja Pektoriusza z Autun ${ }^{7}$ przynosi już informację o sposobie przyjmowania Eucharystii: Przyjmij strawę słodka jak miód, od Zbawiciela świętych. Trzymasz Rybę (Chry-

${ }^{4}$ II Polski Synod Plenarny (1991-1999). Poznań 2001 s. 206.

${ }^{5}$ Arcybiskup Stanisław Gądecki: List pasterski o sposobach przyjmowania Komunii Świętej. Eucharystia tworzy komunię $i$ wychowuje do komunii. „Miesięcznik Kościelny Archidiecezji Poznańskiej”. R. 55: 2005 nr 3 s. 16-19.

${ }^{6}$ Por. J u s t y n: 1 Apologia 66.

${ }^{7}$ Inskrypcja napisana w języku greckim została odkryta w 1839 r. na starożytnym cmentarzy w pobliżu Autun (Francja). Zapis składa się z jedenastu linii, spośród których siedem pierwszych ma charakter doktrynalny i dotyczy chrztu i Eucharystii. Pozostałe mają charakter osobisty modlitwa. Por. L. J. J o h n s o n: Worship in the Early Church. Vol. I: An Anthology of Historical Sources. Collegeville 2009 s. 216-217. 
stusa) w twych dtoniach. Nakarm nas o Panie i Zbawicielu, ciałem Ryby ${ }^{8}$. Bez żadnej wątpliwości możemy zatem stwierdzić, że w II w. wierni przyjmują Komunię na rękę. W tym bardzo krótkim tekście autor akcentuje konieczność głębokiego przeżycia momentu przyjęcia eucharystycznego Chrystusa, natomiast opis obrzędu komunikowania został ograniczony do stwierdzenia, że wierny trzyma Rybę (Chrystusa) w dłoniach.

O praktyce przyjmowania Komunii św. „,na rękę” w kościołach afrykańskich II i III w. pisze Tertulian ( $†$ ok. 220) w traktacie $O$ bławochwalstwie wypominając chrześcijanom, że niektórzy z nich ośmielają się te same ręce wznosić w kulcie bałwanów, i te same ręce zbliżać potem do Ciała Pańskiego ${ }^{9}$. Również Cyprian z Kartaginy $(† 258)$ kilkakrotnie potwierdza praktykę udzielania Komunii św. „na rękę”. Pisze o tym w różnych kontekstach, jednak zawsze jako o praktyce powszechnie stosowanej, np., kiedy potępia postawę lapsi, którzy chcieliby nie odbywając pokuty, przyjmować do zbezczeszczonych rąk Ciało Pańskie, albo skalanymi ustami pić Krew Pańska ${ }^{10}$, lub innym razem, kiedy zachęca chrześcijan do odwagi wobec prześladowców. Pisze wówczas, że prawica chrześcijanina, dzięki temu, iż obejmuje Ciało Pana jest odpowiednio uzbrojona do duchowej walki ${ }^{11}$. Ponadto Cyprian wspomina o zanoszeniu przez świeckich Komunii św. do domów ${ }^{12}$. Także Orygenes $(† 256)$ nakazując wiernym przyjmującym Ciało Pańskie szczególną ostrożność, aby nawet najmniejsza okruszyna nie spadła na ziemię, wyraża w ten sposób nie tylko wiarę w realną obecność Chrystusa pod postacią chleba, ale jednoznacznie wskazuje, iż wierni otrzymywali Komunię św. „na rękę"13.

Świadectwa obu Kartagińczyków i Orygenesa są ważne dla potwierdzenia powszechności przyjmowania Ciała Pańskiego „,na rękę”, jednak dopiero późniejsze świadectwa przynoszą dokładniejsze opisy zasad udzielania Eucharystii wiernym. Najczęściej cytowany jest fragment katechezy Cyryla, biskupa Jerozolimy $(\dagger 386)^{14}$. Omawiając z neofitami liturgię Eucharystii Cyryl wprowadzał ich w zasady przyjmowania Ciała i Krwi Pańskiej (Komunii udzielano pod dwoma postaciami). Otóż biskup odwołując się do Psalmu 33,9: Skosztujcie i zobaczcie, jak stodki jest Pan!, poucza: Nie podniebieniem należy o tym sąd wydawać, nie,

\footnotetext{
8 Por. A. H a m m a n: Życie codzienne w Afryce Pótnocnej w czasach św. Augustyna. Warszawa 1989 s. 251; R. M i 1 b u r n: Early Christian art and architecture. Los Angeles 1988 s. 30.

9 Por. Te r tuli a n: De idololatria 7.

${ }^{10}$ C y p ri a n z Kartaginy: De lapsis 22. Tłum. pol. J. C z u j. POK 19. Poznań 1937 s. 213.

${ }^{11}$ Por. C y p ri a n z Kartaginy: Epistula 58, 9. PSP I, 174. Por. także A. V i 11 i e n: History and Liturgy of the Sacraments. New York 1932 s. 102.

${ }^{12}$ Por. C y p ri a n z Kartaginy: De lapsis 26. Tłum. pol. J. C z u j. POK 19. Poznań 1937 s. 216.

${ }^{13}$ Por. Ory ge ne s: In Exodum homilia XIII, 3. Por. A. S z a f r ań s k i: Teologia liturgii Eucharystycznej. Lublin 1978 s. 119; J. S ł o m k a: Pokarm i ofiara. Łódź 2000 s. 92-93.

${ }^{14}$ Por. X. B a s u r k o: Historia de la liturgia. Barcelona 2006 s. 262.
} 
ale wiara wykluczająca wszelkie wątpliwości. Ci, którzy kosztuja, maja kosztować nie chleba $i$ wina, ale znak Ciata i Krwi Chrystusowej ${ }^{15}$. Dopiero po tym tak wyraźnym pouczeniu, jak chrześcijanin powinien rozumieć wskazaną przez Psalmistę stodycz Pana, że jest to Jego prawdziwe Ciało i Krew, katecheta przechodzi do omówienia obrzędu udzielania i przyjmowania Eucharystii.

Zgodnie z zaleceniem Cyryla Komunię św. przyjmowano „na rękę”. Biskup dokładnie pouczył, w jaki sposób należy przygotować swoje dłonie do przyjęcia konsekrowanej hostii: Nie wyciagaj przy tym płasko ręki i nie rozłączaj palców. Podstaw dłoń lewa pod prawa czyniąc z nich niby tron, gdyż masz przyjać Króla. Do wklęstej ręki przyjmij Ciało Chrystusa i powiedz: »Amen«. Uświęć też ostrożnie oczy swoje przez zetknięcie ich ze świętym Ciałem, baczac, byś zeń nic nie uronit $^{16}$. A zatem ważny jest każdy gest człowieka przyjmującego na swe dłonie Ciało Chrystusowe. Ułożenie rąk, to nie tylko „technika” sprawnego przyjmowania świętego pokarmu, ale to symbolika. Wymagane ułożenie dłoni jest wyrazem wiary chrześcijanina. Wie, że prawdziwie przyjmuje Króla, więc ze swoich dłoni przygotowuje Mu tron. Ta chwila jest okazją do adoracji eucharystycznego Jezusa. Trzymając w swoich dłoniach Ciało Pańskie, należy na nie spojrzeć z wiarą, zatrzymać swój wzrok, który w tym momencie doznaje także uświęcenia. Cyryl zaprasza do jak najpełniejszego przeżycia osobistego spotkania z żywym Jezusem. Wzrok utkwiony w Chlebie eucharystycznym trzymanym w dłoniach, nie pozwala na rozproszenia. Dzięki temu cały człowiek, z duszą i ciałem, jest skoncentrowany na tym niezwykłym wydarzeniu przyjmowania Ciała Pańskiego.

O konieczności skupienia w tej chwili świadczą kolejne rady biskupa Jerozolimy. Wierni mają uważać, aby nic nie uronić z trzymanego w dłoniach konsekrowanego Chleba, który jest droższy od złota i innych szlachetnych kamieni ${ }^{17}$. Akcent całej katechezy został zatem postawiony na akcie wiary w rzeczywistą obecność Chrystusa w widzialnych postaciach chleba i wina ze strony osoby, która uczestniczy we mszy świętej. Taka wiara nie pozwala przystąpić i przeżyć obrzędu Komunii św. w sposób niegodny i bezrefleksyjny. Przyjęcie eucharystycznego Chrystusa „na ręce” pozwala ponadto na dodatkowe skupienie i chwilę adoracji. Biskup Jerozolimy poucza także o sposobie przyjęcia Krwi Pańskiej. Spożywać ją mają z kielicha, a potem - to bardzo ciekawa zachęta katechety powinni wilgotnych jeszcze warg dotknąc rękoma i uświęcić nimi oczy, czoło $i$

${ }^{15}$ C y ryl J e ro zoli m s ki: Catechesis 23, 20. Tłum. pol. W. K a n i a. BOK 14. Kraków 2000 s. 343-344.

${ }^{16}$ C y y l J e ro zoli mski: Catechesis 23,21 . Tłum. pol. W. Ka n i a. BOK 14. Kraków 2000 s. 344.

${ }^{17}$ Tamże. Por. A. S z a f r a ń s k i, dz. cyt., s. 180. 
inne zmysty ${ }^{18}$. Na koniec Cyryl zachęca do postawy dziękczynienia Bogu za łaskę udziału w tak wielkich tajemnicach ${ }^{19}$.

Także Bazyli Wielki (†379), w liście z ok. 372 r. adresowanym do patrycjuszki Cezarii, wyjaśnia zasady nie tylko przyjmowania, ale także przechowywania Najświętszego Sakramentu przez osoby świeckie. Jednak, podobnie jak inni duszpasterze starożytni, podejmując temat sposobu przyjmowania Komunii św. - koncentruje się na konieczności wyznania wiary chrześcijanina w Eucharystię jako pokarmu na życie wieczne. W tym celu biskup Cezarei przytacza fragment ewangelii wg św. Jana: Kto pożywa ciało moje i pije moja krew, ma żywot wieczny $(\mathrm{J} \text { 6,54 })^{20}$ i wskazuje swojej adresatce, że w Kościele od dawna jest praktykowany zwyczaj przyjmowania Komunii św. nie tylko „na ręce”, ale w przypadku braku szafarza nawet ,Z własnych rąk". Ponadto osoby świeckie mogły przechowywać Najświętszy Sakrament w swoich prywatnych domach. Jak wynika z treści listu, tradycja ta była owocem zaistniałych zewnętrznych okoliczności: celebracja Eucharystii tylko w cztery dni tygodnia (Dzień Pański, czwartek, piątek i sobota), czas prześladowań, fizyczna niemożność uczestniczenia w codziennej mszy św. Pisze biskup Cezarei, że należący do ludu niemal zawsze ma Żertwe u siebie $w$ domu i przyjmuje ja, kiedy chce, $z$ rak wtasnych. Kiedy bowiem kaptan dopetnit już raz ofiarowania i przekazat wiernemu Żertwe, ten, kto ja otrzymat jako zupetna, gdy przyjmuje ja codziennie, winien być przeświadczony, $\dot{z}$ e godziwie ja otrzymat $i$ przyjmuje ${ }^{21}$. Z zasady w domach udzielano sobie Komunii św. przed głównym posiłkiem ${ }^{22}$. Dla Bazylego praktyka ta, jak wynika z treści listu, stosowna dość powszechnie, była czymś całkowicie normalnym w ówczesnym Kościele, a autor listu nie widzi w niej żadnej niestosowności i zagrożenia do świętości przechowywanego Ciała Pańskiego ${ }^{23}$. Świadectwo to potwierdza również wiarę wczesnego Kościoła w realną obecność Chrystusa w postaciach Eucharystycznych nie tylko w czasie celebracji Ofiary, ale także później, w konsekrowanych hostiach przechowanych np. w domach ${ }^{24}$.

${ }^{18}$ C y ry 1 J e ro zoli m ski: Catechesis 23 , 22. Tłum. pol. W. Ka n i a. BOK 14. Kraków 2000 s. 344.

${ }^{19}$ Por. tamże.

${ }^{20}$ Por. B a z y li Wi elki: Epistula 93. Tłum. pol. Wł. Krzyżaniak. Warszawa 1972 s. 132.

${ }^{21}$ B a z y 1 i W i e 1 k i: Epistula 93. Tłum. pol. Wł. Kr z y ż a n i a k. Warszawa 1972 s. 133.

${ }^{22}$ Por. A. S z a fr a ń s ki, dz. cyt., s. 86.

${ }^{23}$ Por. B a z y li W i e lki: Epistula 93.

${ }^{24}$ Zwyczaj przechowywania Eucharystii w domach prywatnych zanika w Kościele Rzymskim w V w., natomiast dłużej był praktykowany w Syrii i Egipcie. Ostatecznie praktyka ta zanika w VIII w. W niektórych Kościołach wobec zakazu zabierania konsekrowanych Postaci do domów, wierni otrzymują w to miejsce poświęcony chleb, tzw. eulogia. Por. ks. W. S c h e n k: Udziat ludu w ofierze Mszy świętej. Zarys historyczny. Lublin 1960 s. 8-9; A. S z a f r a ń s k i: Teologia liturgii Eucharystycznej. Lublin 1978 s. 181. 
Teodor z Mopsuestii († 428), w jednej ze swoich homilii, wspomina także o praktyce udzielania Komunii „,na rękę". W swojej relacji na ten temat podkreśla, że cześć dla przyjmowanej Eucharystii wyraża się już w samej procesji. Oczy podchodzących są spuszczone, zaś dłonie, lewa pod prawą, wyrażają wielki szacunek dla przyjmowanego Ciała Chrystusa ${ }^{25}$.

Teodoret z Cyru († ok. 457/466) w swojej Historii Kościoła wspomni o praktyce udzielania Eucharystii „na rękę” mimochodem, relacjonując znane wydarzenia o radykalnej postawie św. Ambrożego $(† 397)$ wobec cesarza Teodozjusza $(† 395)$ po krwawych zajściach w Tesalonikach. Według relacji historyka z Cyru, biskup Mediolanu miał z wyrzutem zapytać cesarza, jak teraz zamierza wyciągnąć splamione krwią ręce i przyjmować nimi Ciało Pańskie? ${ }^{26}$ Również w Hipponie biskup Augustyn udzielał Komunii św. do rą ${ }^{27}$. Św. Augustyn zachęcał do adorowania Eucharystii w czasie Jej przyjmowania ${ }^{28}$. W ten sposób została potwierdzona praktyka udzielania Komunii św. „na rękę” w Kościele zachodnim w IV i V w.

Znacznie więcej uwagi sposobowi przyjmowania Komunii św. przez wiernych poświęcił duszpasterz późnej starożytności chrześcijańskiej, Cezary z Arles $(† 542)$. Zanim przedstawił swoim słuchaczom pouczenie - podobnie jak wielu jego poprzedników - wygłosił katechezę o koniecznym przygotowaniu duszy na ten, tak ważny dla chrześcijanina moment. I on wskazuje na Eucharystię jako pokarm dający życie wieczne. Poucza więc swoich wiernych, aby przystępowali do ołtarza Pańskiego z czystym ciatem $i$ sercem, ze spokojnym i czystym sumieniem. (...) wtedy dojdzie szczęśliwym przejściem od owego ottarza, który jest $w$ niebie $^{29}$. Zwraca uwagę, aby w czasie przyjmowania Komunii św. tak bardzo się skupili, aby wtedy, gdy udzielane jest nam ciato Chrystusa, nic z niego nie upadto z naszych rakk na ziemię ${ }^{30}$.

Kaznodzieja galijski zwraca też uwagę na konieczność zewnętrznego przygotowania się do godnego przyjęcia Eucharystii. Mężczyźni powinni więc umyć ręce, aby w ten sposób wyrazić czystość serca. Czynność tę należało wykonać albo $\mathrm{w}$ domach, albo też w naczyniach $\mathrm{z}$ wodą umieszczonych specjalnie $\mathrm{w}$ tym celu przy wejściu do kościoła ${ }^{31}$. Natomiast kobiety miały przygotować jaśniejąco

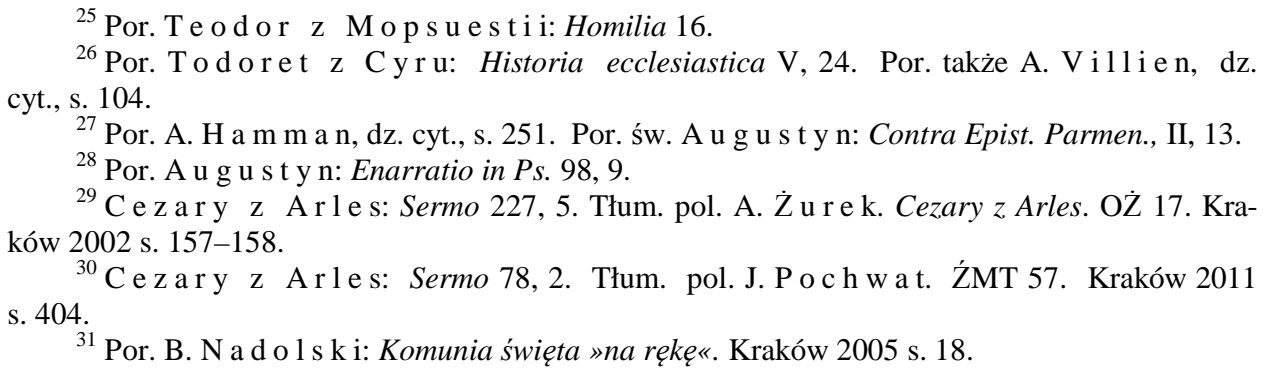


czyste lniane chusty, na które - zgodnie z obowiązującym zwyczajem - otrzymywały Komunię św. ${ }^{32}$. Podobny zwyczaj przyjmowania przez kobiety Komunii św. na specjalne chusty znany był również w Turynie. Potwierdzają to wypowiedzi Maksyma z Turynu ${ }^{33}$. Zwyczaj ten najprawdopodobniej ma swoje źródło w staroperskim ceremoniale dworskim, zgodnie z którym podwładni stawali przed władcą z okrytymi rękami. Ponadto wszystko, co podawano władcy lub też od niego przyjmowano, czyniono rękoma okrytymi odpowiednim welonem ${ }^{34}$. Stosowanie takiej praktyki wobec kobiet w obrzędzie udzielania Komunii św. nie zmieniało faktu, że następnie już własnymi rękoma, zapewne przykrytymi welonem, podawały sobie konsekrowaną hostię do ust ${ }^{35}$.

Zwyczaj podawania Komunii św. „na rękę” praktykowany był jeszcze tak w Kościele Zachodnim jak i Wschodnim w wieku VIII. Beda Wielebny $(† 735) \mathrm{w}$ swoim dziele Historia kościelna narodu angielskiego, opowiadając o chwalebnej śmierci mnicha Cedemona, wspomina, że przyjął on Wiatyk „na rękę" ${ }^{36}$. Jan Damasceński $(† 754)$ pisze również o takiej praktyce udzielania Komunii św. w kontekście rozbudowanej katechezy nt. znaczenia Eucharystii w życiu chrześcijanina. Przekonuje wiernych, że Chleb i wino [po przeistoczeniu] nie sa jednie symbolami (typos) Ciata i Krwi Chrystusa - uchowaj nas Boże od takiej myśli! lecz samym przebóstwionym Ciałem Pana, skoro On sam powiedziat: »To jest (nie: symbol mego ciała, lecz:) moje ciato«, (i nie symbol mojej krwi, lecz:) »moja krew ${ }^{37}$. Dopiero po takim wyznaniu wiary i po przypomnieniu wiernym o konieczności godnego przyjmowania Komunii św. - czego wyrazem jest bojaźń Boża, czyste sumienie i dojrzała wiara - omawia sposób w jaki należy przyjąć Ciało Pańskie. Wskazany układ dłoni jest identyczny do tego, jaki wcześniej wskazywał Cyryl Jerozolimski: dłonie ułożone na kształt krzyża. I podobnie jak biskup Jerozolimy, tak i Jan zachęca do adoracji trzymanej na ręku Hostii: $a$ zwracajac ku Niemu oczy, usta i czoło, przyjmujemy Boski ten wegiel ${ }^{38}$. W ten sposób nawiązuje do proroctwa Izajasza (Iz 6, 6), a w dalszej części katechezy do innych znanych i używanych przez Ojców obrazów Eucharystii, np. ognia ${ }^{39}$.

${ }^{32}$ Por. Ce z ary z Arles: Sermo 227, 5; A. Villie n, dz. cyt., s. 104.

${ }^{33}$ Por. Maks y m z T u r y n u: Sermo 46.

${ }^{34}$ Por. B. N a d o 1 s k i, dz. cyt., s. 18.

${ }^{35}$ Por. także M. R i g h e t t i: Storia liturgica. Vol. III. La Messa. Commento storico-liturgico alla luce del Concilio Vaticano II. Milano 1966 s. 514-515.

${ }^{36}$ Por. B e d a W i e l e b n y: Historia ecclesiastica gentis Anglorum IV, 24. Por. także A. Villi e n, dz. cyt., s. 104.

${ }^{37}$ J a n D a m a s c én s ki : De fide ortodoxa IV, 1148-1149. Tłum. pol. B. W o j k ow s ki. Warszawa 1969 s. 219-220.

${ }^{38} \mathrm{~J}$ a n D a m a s ceń s ki: De fide ortodoxa IV, 1149. Tłum. pol. B. W o j k o w s ki. Warszawa 1969 s. 220.

${ }^{39}$ Obraz Eucharystii jako ognia znany był przede wszystkim w teologii syryjskiej. Używa go w swojej poezji św. E fr e m. Por. Hymni de fide X. Tłum. pol. W. K a n i a. Pieśń o Eucharystii. PSP 11. Warszawa 1973 s. 42-48. 
Damasceńczyk wyraźnie zaprasza do przeżyć niemal mistycznych. W takim klimacie wiary, Eucharystia przyjęta na rękę, doznawała najwyższej czci.

A zatem Ojcowie, choć duszpasterzujący w znacznej od siebie odległości geograficznej i czasowej, to jednak w katechezach omawiających zasady przyjmowania Komunii św. ,na rękę”, wiele uwagi poświęcają odpowiedniemu przygotowaniu i skoncentrowaniu wiernych na przeżywanym misterium wiary ${ }^{40}$. Ich katecheza nie jest więc jedynie formą przygotowania technicznego: postawa całego ciała, układ rąk. Akcent położony jest na przeżycie tego momentu jako spotkania z żywym Chrystusem obecnym pod postaciami chleba i wina.

Niestety mimo, tak gruntownej katechezy, nie wszyscy wierni przyjmowali godnie Eucharystię. Wspomina o tym Jan Chryzostom, który także poświadcza istniejącą praktykę przyjmowania Komunii św. „na rękę”, gani jednak swoich słuchaczy, że przystępują do sakramentów św. nieprzygotowani wewnętrznie. Pyta zatem swoich słuchaczy: Jakże staniesz przed trybunatem Chrystusa ty, który ośmielasz zbliżyć się do Jego Ciała ze splamionymi rękami i wargami ${ }^{41}$ Ufa, że nikt nie zbliży się do stołu Pańskiego z brudnymi rękoma. Wynika stąd, że niektórzy wierni dbali o zewnętrzną czystość, zaniedbując jednocześnie wewnętrzne przygotowanie, dużo ważniejsze dla owocnego przyjęcia Komunii św.

\section{Problem Komunii św. „na rękę” w uchwałach synodów}

Należy podkreślić, że problematyka sposobu udzielania Komunii św. wiernym nie była częstym przedmiotem dyskusji synodów starożytności chrześcijańskiej, zatem udzielanie Komunii św. na „rękę” było powszechnie przyjęte i nie budziło żadnych poważnych wątpliwości ani tym bardziej sporów.

Pośrednio o przyjmowaniu Komunii św. „na rękę” pouczają biskupi zebrani na synodzie w Saragossie w 380 r. W kanonie 3 przyjęto następującą zasadę: Kto przyjmuje w Kościele Eucharystię, ale jej nie spożywa, ma być wytaczony ${ }^{42}$. Podobną uchwałe przyjmie zgromadzony w 397 r. I synod w Toledo ${ }^{43}$. Z tekstu kanonów obu tych synodów można wnioskować, że w Hiszpanii w IV w. udzielano również Komunii św. „na rękę”, skoro istniało niebezpieczeństwo, iż ktoś nie spożywając Jej, mógł Ją wynieść poza Kościół. Przepis ten należy rozumieć w kontekście uchwał całego synodu, który w dużej części poświęcono pryscylianizmowi oskarżanemu także o magię. Z lęku więc o profanację Eucharystii zaka-

\footnotetext{
${ }^{40}$ Por. P. Farn é s S c here r: Pastoral de Eucaristía. Barcelona 1991 s. 142.

${ }^{41} \mathrm{~J}$ a n Ch r y z o s t o m: In epistulam ad Ephesios 3, 3-5. Tłum. Pol. T. S i n k o: Eucharystia pierwszych chrześcijan. OŻ 7. Kraków 1987 s. 227.

${ }^{42}$ Synod w Saragossie: Kanon 3. Tłum. pol. A. B o b e r W: H. P i e t r a s: Dzień święty. Kraków 1992 s. 132

${ }^{43}$ Por. I Synod w Toledo: Kanon 14.
} 
zywano zabierania Jej do domu, mimo że w Kościele starożytnym było to praktyką dość powszechną ${ }^{44}$.

Natomiast synod w galijskim Auxerre (ok. 581 r.) precyzuje sposób przyjmowania Komunii św. przez kobiety, co wcześniej omawiali już w swoich kazaniach Maksym z Turynu i Cezary, biskup Arles ${ }^{45}$. W kanonie 42 synodu Ojcowie zapisali: Każda kobieta, gdy przystępuje do komunii, ma mieć własne »dominicale«. Gdyby któraś go nie miała, nie może przystapić do komunii, aż do innego dnia Pańskiego ${ }^{46}$. Dominicale to welon wykonany z płótna, na który kobiety przyjmowały Komunię ${ }^{47}$. Przez welon także, nie dotykając gołymi dłońmi postaci Eucharystycznej, kobiety same udzielały sobie Komunii. Była więc to bez wątpienia również forma przyjmowania Komunii św. „na ręce”.

Spośród wszystkich synodów odbytych w starożytności najbardziej otwarcie o praktyce udzielania Komunii św. „na rękę” wypowiada się II synod Trullański (692 r.). Ojcowie synodalni nie tylko potwierdzają taką praktykę komunikowania, ale nawet nakazują ją, sprzeciwiając się przyjmowaniu przez wiernych Eucharystii do naczyń (patena?) wykonanych ze złota lub innego równie drogocennego materiału. Bardzo interesująca wydaje się motywacja takiego postanowienia, przedstawiona przez ojców synodalnych. Wskazują oni na wielką godność człowieka, który został stworzony na obraz i podobieństwo Boże. Godność człowieka została podkreślona przed wszystkim w wywyższeniu go ponad wszelkie stworzenia dzięki zbawczej męce Chrystusa. Zatem ręce człowieka uczynione na obraz Boży, złożone na kształt krzyża są godne, aby przyjąć Ciało Pańskie. Nie jest natomiast godne przyjmowanie Komunii na ręką ludzką uczynione bezduszne naczynie ${ }^{48}$. Jednocześnie kanon wskazuje, iż przyjmujacy ciało i krew Chrystusa, bezustannie przeobraża się dla życia wiecznego, duszę $i$ ciało uświęcając przyjmowaniem Bożej łaski ${ }^{49}$. Ojcowie synodalni musieli do tego przepisu przywiązywać wielkie znaczenie, skoro jego wypełnienie obwarowują karą ekskomuniki na każdego duchownego, który udzieliłby wiernym Komunii św. do naczynia, a nie na ręce. Kanon nie wspomina natomiast ani słowem o jakichkolwiek konsekwencjach wobec wiernych, którzy w taki sposób chcieliby przyjąć Eucharystię. Być może dla ojców ważne było wskazanie konieczności przyjmo-

\footnotetext{
${ }^{44}$ Por. H. P i e tr a s: Dzień święty. Kraków 1992 s. 132; O. N u s s b a u m: Geschichte und Reform des Gottesdienstes. Paderborn 1996 s. 160.

${ }^{45}$ Por. M a k s y z T u r y nu: Sermo 46; C e zary z Arle s: Sermo 227, 5.

${ }^{46}$ Synod w Auxerre: Kanon 42. Tłum. pol. H. P i e t r a s: Dzień święty. Kraków 1992 s. 137.

${ }^{47}$ Por. B. N adolski: Leksykon liturgii. Poznań 2006 s. 335. Poenitentiale PseudoCummaeani XIV, 9 z VIII wieku zezwalała kobietom na przyjmowanie Komunii w czarnym welonie. Por. Libri poenitentiales. Kraków 2011 s. 113-113*.

${ }^{48}$ Por. II Synod Trullański: Kanon 101.

${ }^{49}$ II Synod Trullański: Kanon 101. Tłum. pol. ks. A. N o s k o: Kanony Kościoła Prawostawnego. Hajnówka 2000 s. 106. Por. O. N u s s b a u m, dz. cyt., s. 158.
} 
wania Eucharystii na rękę, a nie do naczynia, aby w ten sposób podkreślić moment uświęcenia ciała poprzez kontakt dłoni z najświętszymi postaciami.

\section{III. Świadectwa praktyki udzielania Komunii św. „do ust”}

Choć uważa się, że praktyka przyjmowania Komunii św. „na rękę” była powszechnie stosowana w Kościele starożytnym, to można jednak odnaleźć również dowody udzielania Komunii św. „do ust”. Grzegorz Wielki opisuje historię uzdrowienia pewnego człowieka, niemego i chromego przez papieża Agapita $(535-536)^{50}$. Biskup Rzymu odprawił mszę św. przy chorym i jego rodzinie, a następnie podając mu rękę postawił go na nogi. Kiedy zaś podał mu do ust Komunię św. - niemy odzyskał zdrowie ${ }^{51}$. Tekst ten choć jednoznacznie wskazuje na udzielenie choremu Ciała Pańskiego do ust, to jednak okoliczności udzielenia Go w taki sposób były wyjątkowe. Jest bowiem możliwe, że Agapit udzielił Komunii św. do ust, nie dlatego, że taka była praktyka Kościoła, ale dlatego, aby w ten sposób poprzez cudowne działanie Eucharystii uzdrowić niemego człowieka. Trudno więc uznać wypowiedź Grzegorza Wielkiego jako dowód istnienia w Kościele rzymskim VI wieku praktyki udzielania Komunii św. „do ust”.

Niezaprzeczalnym natomiast potwierdzeniem istnienia praktyki udzielania Komunii św. „do ust” na terenach Galii jest treść kanonu 3, przyjętego w 650 r. na synodzie w Rouen. Ustalono wówczas, że nie wolno udzielać Komunii św. „na rękę” żadnej osobie świeckiej. Wierni mogą przyjmować Eucharystię jedynie do ust ${ }^{52}$. Uważa się, że przepis ten jest wyrazem zmieniającej się struktury Kościoła. Zdaniem X. Basurko, w późnej starożytności chrześcijańskiej dochodzi do głosu przekonanie o wyjątkowej świętości duchownych, którzy jako jedyni są godni dotykać świętych postaci eucharystycznych ${ }^{53}$.

\section{Wnioski}

1. Dostępne źródła pozwalają jednoznacznie stwierdzić, że w starożytności chrześcijańskiej powszechną praktyką Kościoła było udzielania Komunii św. „na rękę".

2. Ojcowie Kościoła w swoich katechezach nt. sposobu przyjmowania Komunii św. akcentowali przede wszystkim duchowe przeżycie tego istotnego dla wiernych momentu. Dopiero potem zajmowali się omówieniem

${ }^{50}$ Por. A. V i 11 i e n, dz. cyt., s. 106.

${ }^{51}$ Por. Grzeg orz Wi e 1 ki: Dialogi III, 3. Tłum. pol. Wł. S zołdrski. PSP 2. Warszawa 1969 s. 101.

${ }^{52}$ Por. Synod w Rouen: Kanon 3.

${ }^{53}$ Por. X. B a s u r k o, dz. cyt., s. 263. Por. także E. P a 1 a z z o: Liturgie et société au Moyen Âge. Paris 2000 s. 26. 
układu dłoni w chwili przyjmowania Komunii św. Starali się też uwrażliwić wiernych na uważne przyjmowanie Eucharystii, aby nawet najmniejsza cząstka świętych postaci nie upadła na ziemię.

3. Sposób przyjmowania Eucharystii przez wiernych nie musiał być sprawą kontrowersyjną, nie musiało też być w tej materii żadnych poważniejszych wykroczeń, skoro problematykę tę podjęło zaledwie kilka synodów. i to przeważnie w kontekście zagrożeń związanych z konkretną herezją.

4. Kwestię Komunii św. podawanej „do ust” podejmuje dopiero synod w Rouen

w 650 r., a więc u schyłku starożytności chrześcijańskiej, kiedy to dokonują się zmiany w pojmowaniu urzędu kapłańskiego i roli świeckich w życiu Kościoła. 